\title{
Long-term Trends in Coral Reef Fish Yields and Exploitation Rates of Commercial Species from Coastal Kenya
}

\author{
Boaz Kaunda-Arara ${ }^{1}$, George A. Rose ${ }^{2}$, Mucai S. Muchiri ${ }^{1}$ and Rashid Kaka ${ }^{3}$ \\ ${ }^{1}$ Department of Fisheries, Moi University, P.O. Box 1125, Eldoret, Kenya ${ }^{2}$ Marine Institute of Memorial \\ University, P.O. Box 4920, St John's, NL, AlC 5R3, Canada; ${ }^{3}$ Fisheries Department, Ministry of Livestock \\ and Fisheries, Mombasa, Kenya
}

Key words: coral reef fish, yield, long term trends, commercial fishing, Kenya

\begin{abstract}
Analysis of long-term (1978-2001) marine fisheries data showed that Kenyan coralreefs produced an estimated 2-4 metric $\mathrm{t} / \mathrm{km}^{2} /$ year of demersal fish. A rapid overall decline in landings occurred during the 1990s. Yields (t/ $/ \mathrm{km}^{2} /$ year) showed bimodal peaks in 1982 (2.98) and 1991 (2.90). The average total landings dropped by 55\% during the last decade following peak landings in 1982. Landings of the commercially important families (e.g., Siganidae, Lethrinidae, Lutjanidae and Serranidae) declined by about $40 \%$ during the last decade, with the groupers (Serranidae) showing the steepest (72\%) decline. Analysis of landings per administrative district showed a $78 \%$ decline in the densely populated Mombasa district between the periods 1983-1991 and 1992-2001. The less populated districts have registered stable (e.g., Kilifi) to increasing (e.g., Kwale) catches over time. An autoregressive moving average (ARIMA) model forecast of landings predicted a gradual decline in catches during the next decade (20022011) with a trend slope of $-0.01 \mathrm{t} / \mathrm{km}^{2}$. Length-frequency analysis for the commercially important species indicated above optimum exploitation (E) and fishing mortality (per year) rates for the sky emperor, Lethrinus mahsena $(\mathrm{E}=0.64 ; \mathrm{F}=2.48)$ and lower but strong rates for the emperor, L. sangueinus $(\mathrm{E}=0.51 ; \mathrm{F}=0.93)$. The more abundant and commercially important whitespotted rabbitfish, Siganus sutor, showed equally strong rates $(\mathrm{E}=0.56 ; \mathrm{F}=1.44$ year $)$. A precautionary approach in the management of Kenya's coral-reef fisheries is recommended.
\end{abstract}

\section{INTRODUCTION}

Fishing is the dominant extractive activity in Oceania and an important source of income and sustenance in coastal communities worldwide. However, in the past decade many marine fisheries resources have declined (FAO, 1995). Although ocean climate variation has likely played an important role in many regional declines (Lauck et al., 1998; Drinkwater \& Mountain, 2002), the most important factor has been overfishing (Pauly \& Christensen, 1995; Hutchings, 2000; Rose et al., 2000). The effects of fishing have been the subject of recent reviews (Jennings \& Polunin, 1996; Jennings \& Kaiser, 1998). Growth overfishing

Corresponding author:BK-A.

E-mail:b_kaunda@yahoo.com reduces the size and yield of target species (Koslow et al., 1988; Russ, 1991; Munro, 1983), recruitment overfishing reduces the recruitment success of populations (Jennings \& Lock, 1996) while ecosystem overfishing alters species interactions and habitat quality (McClanahan, 1995). Marine fishes have been thought to be resilient to these effects (Musick, 1999), but such resilience has likely been overstated, and will depend on the degree and frequency of impact and the life history traits of target species (Sadovy, 2001). In developing countries, the effects of fishing are exacerbated by inadequate resources available to management agencies and increasing human populations (McManus, 1997). The outdated 
notion that fisheries resources are unlimited, often reinforced by increasing annual catches, has led to overfishing of many tropical fisheries resources (Pauly et al., 2002).

In East Africa, coral reef fisheries have a long history (Brochman, 1984). In Kenya, reef fisheries are exploited by approximately 8000 artisanal fishermen. These fishermen mostly use traditional dugout canoes on grounds that include most of the lagoons between shore and the fringing reefs (Brochman, 1984). East African reefs are thought exploited at sustainable levels or to be somewhat overfished (McClanahan \& Obura, 1995). However, there are no estimates of yields or exploitation rates for these fisheries, largely as a consequence of inadequate landing statistics (UNEP, 1998). In other tropical reef systems, few estimates of long-term yields of coral reef fisheries have been reported (Dalzel, 1996; Jiddawi \& Stanley, 1999; Mapya et al., 2002), but crossregional comparisons may be problematic because of local variations in reef areas and types, depth and fishing effort (Russ, 1991). Recent increases in human population in East Africa (e.g., $4.2 \%$ per year in Kenya) have likely increased the demand for marine food fish. However, the effects of any such increased demand on reef fish resources have not been quantified.

Studies on long-term yields of coral reef fisheries are few (Mapya et al., 2002), but can provide important information to management on the state of stocks. In this paper, we document longterm trends in the yields of coral reef-associated fish families in Kenyan waters of the western Indian Ocean. We also provide estimates of exploitation and fishing mortality rates for the principal commercial species, and develop a time series model of landings with long-term projections.

\section{MATERIALS AND METHODS}

The Kenya Fisheries Department routinely collects fish landing statistics along Kenya's approximately 600-km-long coastline (Fig. 1). Fish scouts who are supervised by Fisheries Assistants record landed weight of fish by taxonomic families at designated landing beaches. The data from all landing sites within the administrative units or districts (e.g., Mombasa, Kilifi, Kwale and Lamu) are compiled into a national annual statistical bulletin. Landing data contained in the annual statistical bulletins from 1978 to 2001 were analysed in this study for reef-associated families (Lethrinidae, Lutjanidae, Siganidae, Scaridae, Acanthuridae, Serranidae, and an 'others' category). Catches of non-reef pelagic families (mostly Clupeidae and Carangidae) are highly variable and were excluded.

Exploitation levels and fishing mortality rates were derived from length-frequency data obtained from commercial trap landings. At bi-weekly intervals from May 2000 to April 2 trained assistants sampled trap fish at four active fish landing sites adjacent to Watamu and Malindi Marine National Parks (Fig. 1). Total length (to the nearest $\mathrm{mm}$ ) of random samples of landed fish species, number of traps per fisherman, fishing ground and the fisherman's name were recorded. Length-frequency data of the commercially important fish species (the whitespotted rabbitfish, Siganus sutor, the sky emperor, Lethrinus mahsena and the trumpet emperor, L. miniatus) were used to estimate exploitation and fishing mortality rates and population growth parameters.

\section{Data analyses}

It is estimated that artisanal fishermen in coastal Kenya operate within an area of approximately 800 $\mathrm{km}^{2}$ of lagoons that extend between the shore and continuous fringing reefs at depths less than $5 \mathrm{~m}$ at low tide (McClanahan \& Obura, 1995; UNEP, 1998). This reef area was used to standardise catches (tonnes $/ \mathrm{km}^{2}$ ). Time series of landings (in tonnes $/ \mathrm{km}^{2} /$ year) were used to analyse temporal trends in catches of the major demersal families of coral reef fish (e.g., Siganidae, Lethrinidae, Lutjanidae, Scaridae, Acanthuridae, Serranidae and 'others').

A locally-weighted scatterplot smoother (LOWESS) (Cleveland, 1979) was used to fit smoothed trend lines to the full data series using the MINITAB package. The LOWESS is based on a weighted least squares algorithm that gives local weights the most influence while minimising the effects of outliers (Cleveland, 1979). A smoothness parameter (f) of 0.2 was found to adequately 


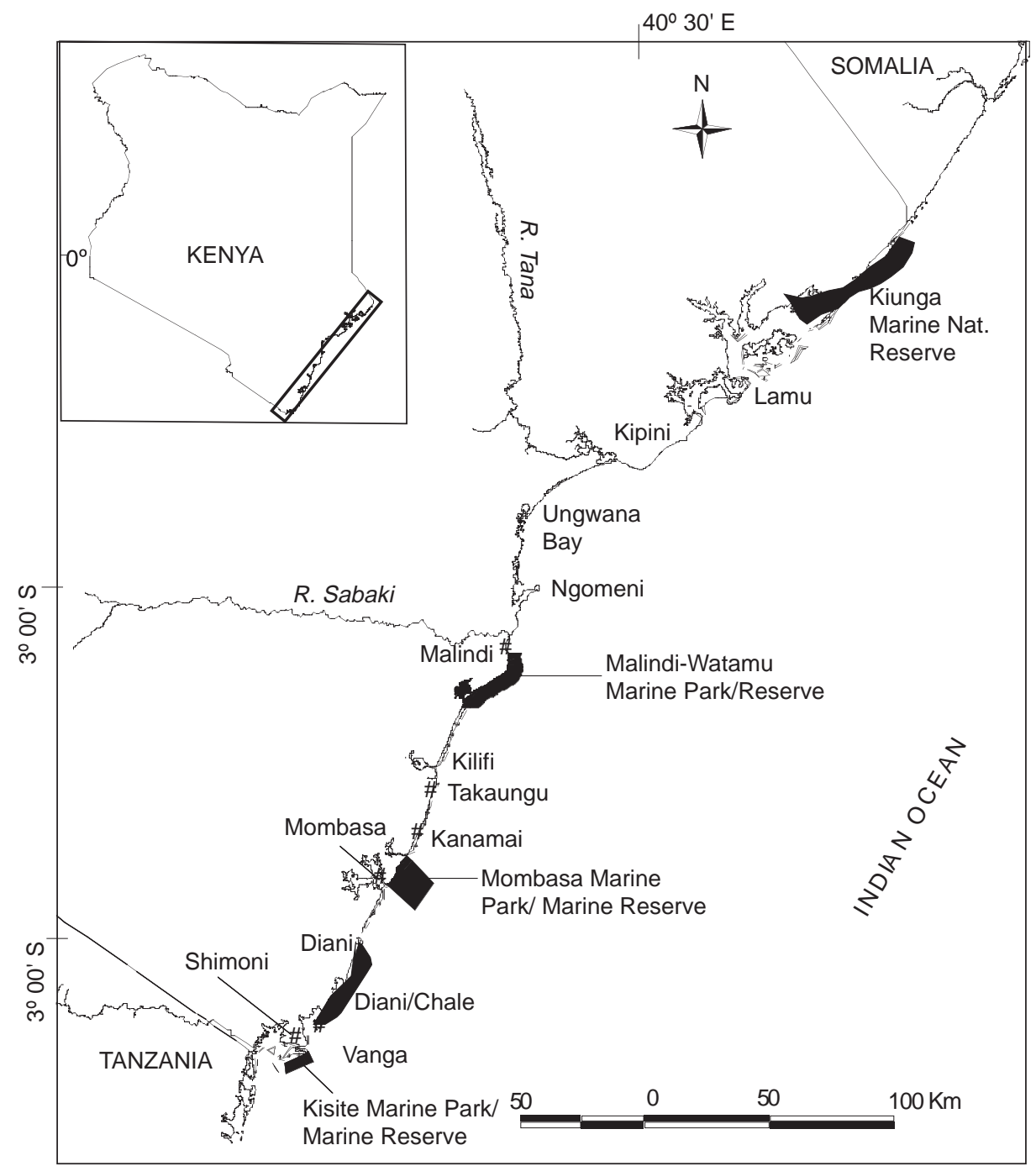

Fig. 1. Kenyan coastline showing the major fish landing sites and marine national parks

smooth the data without distorting the main temporal patterns. Additionally, an autoregressive integrated moving average (ARIMA) model (Box $\&$ Jenkins, 1976) was used to forecast landings for the next decade (2002-2011). An ARIMA (111) model that integrates first order autoregressive (AR) and moving average (MA) model parameters with first differencing of the annual catches (Rothschild et al., 1996; O’Donovan, 1983) was used to forecast catches as:

$\mathrm{y}_{\mathrm{t}}=\theta_{0}+\phi_{1} \mathrm{y}_{\mathrm{t}-1}+\mathrm{a}_{\mathrm{t}}-\theta \mathrm{a}_{\mathrm{t}-1}$

where, $y_{t}$ is the first difference of the catches at time t, $\phi$ and $\theta$ are AR and MA parameters, respectively, $a_{t}$ is a random error term and $\theta_{0}$ is the model constant. The model assumes stationarity and homogeneity of means and variances, respectively. The means and variances of the output series (catches) were made stationary and homogeneous by first differencing and $\log _{\mathrm{e}}$ transformation of the data, respectively. The slope (s) of the forecast trend in landings during the next ten years (2002-2011) was derived by following O’Donovan's (1983) formula:

$\mathrm{s}=\theta_{0} /\left(1-\phi_{1}\right)$ 
The ARIMA model is considered parsimonious in analysing data whose underlying structure is unknown and with individual observations that are prone to error (Box \& Jenkins, 1976). The longterm landing data were divided into 3 time intervals (1978-1982, 1983-1991 and, 1993-2001) based on a preliminary assessment of the temporal pattern of landings. A one-way ANOVA was used to test for significant differences in landings (metric tonnes) between the 3 time periods. All data were first tested for normality and homoscedasticity using Kolmogorov's test and Levene's test, respectively, (Zar, 1975). Where variances were significantly different within the families (e.g., Serranidae and Scaridae) and in the districts (e.g., Mombasa), the catch was first $\log _{\mathrm{e}}$-transformed before ANOVA was performed. Where the mean catch between the time periods were found to be different (ANOVA, $\mathrm{P}<0.05$ ), a Bonferroni test was used for post hoc analysis.

Exploitation level $(E)$ and fishing mortality rate $(F)$ and growth parameters (e.g., instantaneous annual growth rate, $K$, and the asymptotic length, $L_{\infty}$ ) were estimated for the three major commercial species using length-frequency analysis (LFA). LFA was carried out using length-based routines in the FiSAT package (Gayanilo et al., 1995). In order to increase the modal sizes, length-frequency data were pooled tri-monthly for the sky and the trumpet emperors for the period May 2000 to January 2002. Monthly length-frequency (June 2000 to March 2002) data were analysed for the more abundant whitespotted rabbitfish. Having obtained estimates of the growth parameters ( $K$ and
$L_{\infty}$ ) from ELEFAN I sub-package in FiSAT, ELEFAN II was used to estimate instantaneous total $(Z)$ and natural mortality $\left(M\right.$ at $\left.27^{\circ} \mathrm{C}\right)$ rates from linearised length-converted catch curve and Pauly's empirical formula (Pauly, 1980, 1984):

In $\mathrm{M}=-0.0152-0.279 \ln \mathrm{L}_{\infty}+0.6543 \ln \mathrm{K}+$ $0.463 \ln \mathrm{T}$

where $\mathrm{T}$ is the annual sea surface temperature (27 $\left.{ }^{\circ} \mathrm{C}\right) . F$ was then obtained from the difference between $Z$ and $M$. The exploitation rate $(E)$ for each of the three species was derived from the ratio, F/ Z, (Gulland, 1971). The exploitation rate indicates whether the stock is lightly $(E<0.5)$ or strongly $(E>0.5)$ exploited, based on the assumption that the fish are optimally exploited when $F=M$ or E $=0.5$ (Gulland, 1971).

\section{RESULTS}

\section{Total catch}

The long-term total landings of demersal coral reef fishes averaged $2.11 \pm 0.49 \mathrm{t} / \mathrm{km}^{2} /$ year. Annual landings peaked in $1982\left(2.98 \mathrm{t} / \mathrm{km}^{2} /\right.$ year $)$ and 1991 ( $2.90 \mathrm{t} / \mathrm{km}^{2} /$ year) (Fig. 2a). Following the peak in 1982 the catches dropped by $23 \%$ to 2.3 in 1984 and remained relatively stable during 1983-1991 when landings averaged $2.53 \pm 0.20 \mathrm{t} / \mathrm{km}^{2} /$ year (Table 1 and Fig. 2a). Following this period of relative stability, annual landings declined by $30 \%$ from 1991 to 1992 (2.03), with a further $25 \%$ decline in subsequent years to the lowest levels,

Table 1. Differences in mean catch of coral reef fish families and total catch $\left(\mathrm{t} / \mathrm{km}^{2} /\right.$ year) between years $(1978-$ 1986, 1987-1992 and 1993-2001) in coastal Kenya

\begin{tabular}{|c|c|c|c|c|c|c|}
\hline \multirow[b]{2}{*}{ Families } & \multicolumn{3}{|c|}{ Mean catch \pm s.d. } & \multicolumn{2}{|c|}{ ANOVA } & \multirow[b]{2}{*}{ Bonferroni post hoc } \\
\hline & $1978 / 1982$ & 1983/1991 & $1992 / 2001$ & $\mathrm{~F}$ & $\mathrm{P}$ & \\
\hline Siganidae & $0.71 \pm 0.09$ & $0.75 \pm 0.07$ & $0.45 \pm 0.09$ & 35.16 & 0.00 & $78 / 82=83 / 91>92 / 2001$ \\
\hline Lethrinidae & $0.74 \pm 0.13$ & $0.78 \pm 0.03$ & $0.48 \pm 0.08$ & 38.18 & 0.00 & $78 / 82=83 / 91>92 / 2001$ \\
\hline Lutjanidae & $0.27 \pm 0.06$ & $0.24 \pm 0.04$ & $0.15 \pm 0.03$ & 13.93 & 0.00 & $78 / 82=83 / 91>92 / 2001$ \\
\hline Scaridae & $0.14 \pm 0.05$ & $0.29 \pm 0.06$ & $0.21 \pm 0.04$ & 16.16 & 0.00 & $83 / 91>92 / 2001>78 / 82$ \\
\hline Acanthuridae & $0.05 \pm 0.02$ & $0.07 \pm 0.01$ & $0.06 \pm 0.02$ & 2.87 & 0.08 & $78 / 82=83 / 91=92 / 2001$ \\
\hline Serranidae & $0.19 \pm 0.07$ & $0.15 \pm 0.04$ & $0.09 \pm 0.01$ & 12.35 & 0.00 & $78 / 82=83 / 91>92 / 2001$ \\
\hline Others & $0.21 \pm 0.06$ & $0.25 \pm 0.04$ & $0.20 \pm 0.03$ & 4.12 & 0.03 & $83 / 91>92 / 2001=78 / 82$ \\
\hline Total & $2.31 \pm 0.46$ & $2.53 \pm 0.20$ & $1.65 \pm 0.24$ & 24.43 & 0.00 & $78 / 82=83 / 91>92 / 2001$ \\
\hline
\end{tabular}


observed in 2000 (1.3). The average landings for the period 1992-2001 $\left(1.65 \pm 0.21 \mathrm{t} / \mathrm{km}^{2} /\right.$ year $)$ were significantly lower than landings from 1978$1982(29 \%)$ and 1983-1991 (35\%) (Table 1).

\section{Catch by taxonomic group}

The fish families landed showed differences in trends (Fig. 2). The rabbitfishes (family Siganidae) showed increasing landings during 1978-1982 $\left(0.71 \pm 0.09 \mathrm{t} / \mathrm{km}^{2} /\right.$ year $)$ that stabilised during 1983-1991 (0.75 $\pm 0.07 \mathrm{t} / \mathrm{km}^{2} /$ year). However, the 1992-2001 average landings $(0.45 \pm 0.09)$ were significantly lower (ANOVA, $\mathrm{P}<0.05$, Table 1) than for the earlier periods, with the lowest catches in 2000 (0.32 t/ $\mathrm{km}^{2} /$ year) (Fig. 3b). The emperors (family Lethrinidae), had peak landings in 1982 $\left(0.90 \mathrm{t} / \mathrm{km}^{2} /\right.$ year) and $1991\left(0.83 \mathrm{t} / \mathrm{km}^{2} /\right.$ year) (Fig. $3 \mathrm{c})$. Average landings of emperors did not differ between 1978 and $1982\left(0.74 \pm 0.13 \mathrm{t} / \mathrm{km}^{2} /\right.$ year $)$ and 1983 and 1991 (0.78 $\pm 0.03 \mathrm{t} / \mathrm{km}^{2} /$ year $)$, however, the landings during the last decade, 1992$2001\left(0.48 \pm 0.08 \mathrm{t} / \mathrm{km}^{2} /\right.$ year $)$, were significantly lower than for the earlier periods (Table 1).

The groupers (family Serranidae), had one prominent peak during 1982-1983 (0.32 t/ $\mathrm{km}^{2} /$ year) (Fig. 2d), however, unlike the other families, catches subsequently declined steeply $(72 \%)$ to an average of $0.09 \pm 0.01 \mathrm{t} / \mathrm{km}^{2} /$ year during the period 1992-2001, which was significantly lower
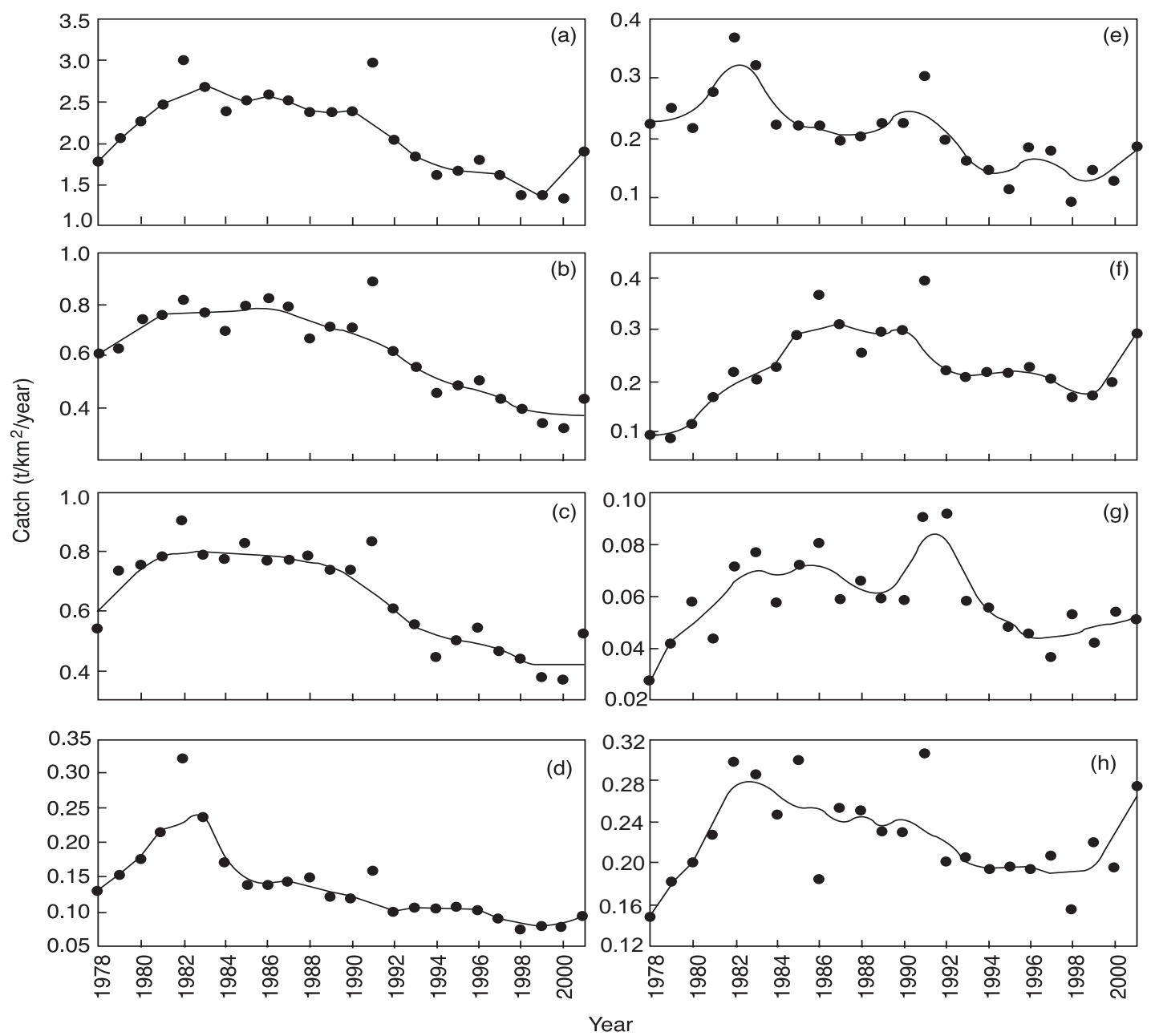

Fig. 2. Long-term trends in annual landings $\left(\mathrm{t} / \mathrm{km}^{2} / \mathrm{year}\right)$ of demersal coral reef fish families from $1978 \mathrm{to} 2001 \mathrm{in}$ coastal Kenya. Continuous lines show the LOWESS trend fit to landings, while $(\bullet)$, show the actual landings. (a) All families (b) Siganidae (c) Lethrinidae (d) Serranidae (e) Lutjanidae (f) Scaridae (g) Acanthuridae (h) Others 
(ANOVA, P < 0.05) than earlier periods (Fig. 3d and Table 1). The snappers (family Lutjanidae), had peak landings in 1982 (0.36) and 1991 (0.30), with a subsequent decline to low levels in 2000 $\left(0.12 \mathrm{t} / \mathrm{km}^{2} /\right.$ year) (Fig. 2e). The other families, which are less important in commercial catches (e.g., Scaridae and Acanthuridae) showed rising catches (1978-1984) followed by a general decline during the 1990s, but the landings for the Scaridae showed a rising trend in recent years (Fig. 2f) as did the 'others' (e.g. Labridae, Gaterinidae, Holocentridae, etc.) category (Fig. $2 \mathrm{~g}$ and h).

\section{Landings per district}

Landings categorised according to administrative districts showed variable trends (Fig. 3). The densely populated Mombasa district (approx. 280 persons $/ \mathrm{km}^{2}$, UNEP, 1998) registered peak landings in 1986 (908) followed by a consistent decline in subsequent years to the lowest levels observed in $1997\left(118 \mathrm{t} / \mathrm{km}^{2}\right)$ (Fig. 3a). The average landings during 1992-2001 $\left(159 \pm 31 \mathrm{t} / \mathrm{km}^{2}\right)$ were significantly lower (78\%) than during 1983-1991 $\left(722 \pm 156 \mathrm{t} / \mathrm{km}^{2}\right)$ (Table 2). Kilifi district (approx. 57 persons $/ \mathrm{km}^{2}$ ) had an isolated peak landings in $1982\left(571 \mathrm{t} / \mathrm{km}^{2}\right)$, after which landings dropped (69\%) to a low in 1985 (175), followed by relative stability (1985-1997) and a decline in the late 1990s (Fig. 3b). Overall there were no significant differences in quantities landed at Kilifi between periods (ANOVA, P > 0.05, Table 2). The less populated Lamu district (approx. 33 persons $/ \mathrm{km}^{2}$ ) showed an erratic trend in landings that generally declined over time following a peak in 1983 (Fig. $3 \mathrm{c})$. The average quantities landed at Lamu during $1978-1982\left(763.8 \pm 150 \mathrm{t} / \mathrm{km}^{2}\right)$ were significantly higher than the rest of the periods (Table 2). In contrast, the more populated Kwale district

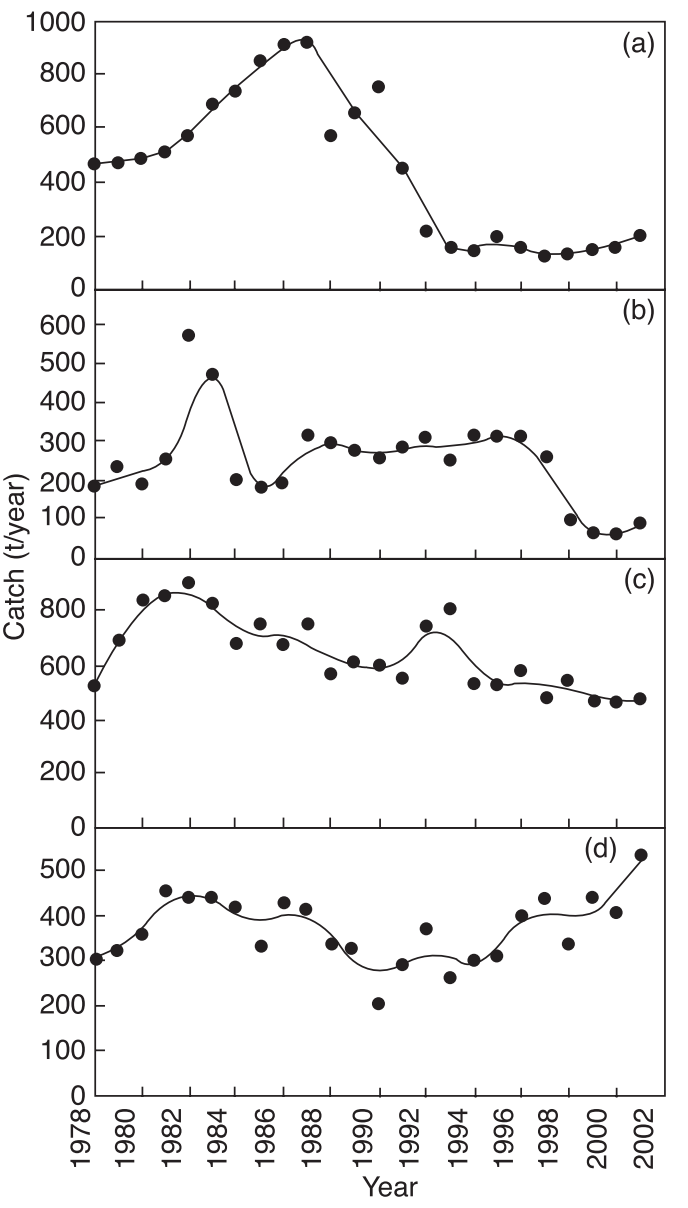

Fig. 3. Long-term trends in the annual landings ( $t$ / year) of demersal coral reef fish in the active fish landing districts in coastal Kenya. Continuous lines show the LOWESS trend fit to landings, while $(\bullet)$, show the actual landings (a) Mombasa, (b) Kilifi, (c) Lamu, (d) Kwale.

(approx. 53 persons $/ \mathrm{km}^{2}$ ) showed an initial increase in landings (1978-1982) followed by a gradual drop to lowest level in 1991. The district registered increased catches during the 1990s (Fig. 3d).

Table 2. Differences in mean annual landings (MT/year) of demersal coral reef fish in the administrative districts of coastal Kenya during the periods 1978-1982, 1983-1991 and 1992-2001

\begin{tabular}{|c|c|c|c|c|c|c|}
\hline \multirow[b]{2}{*}{ District } & \multicolumn{3}{|c|}{ Mean catch \pm s.d. } & \multicolumn{2}{|c|}{ ANOVA } & \multirow[b]{2}{*}{ Bonferroni post hoc } \\
\hline & $1978 / 1982$ & $1983 / 1991$ & $1992 / 2001$ & $\mathrm{~F}$ & $\mathrm{P}$ & \\
\hline Mombasa & $496.4 \pm 42.2$ & $722.4 \pm 155.6$ & $158.8 \pm 31.2$ & 154.49 & 0.00 & $83 / 91>78 / 82>92 / 2001$ \\
\hline Kilifi & $283.4 \pm 163.6$ & $269.7 \pm 91.0$ & $200.4 \pm 115.5$ & 1.17 & 0.33 & $78 / 82=83 / 91=92 / 2001$ \\
\hline Lamu & $762.8 \pm 155.5$ & $666.8 \pm 92.4$ & $583.1 \pm 123.6$ & 3.84 & 0.04 & $78 / 82>83 / 91=92 / 2001$ \\
\hline Kwale & $374.6 \pm 68.5$ & $353.0 \pm 79.2$ & $378.4 \pm 81.5$ & 0.27 & 0.77 & $78 / 82=83 / 91=92 / 2001$ \\
\hline
\end{tabular}




\section{Forecast landings (2002-2011)}

Based on ARIMA (111) model, the combined catches of all the families were used to forecast total landings for the next decade following the last recorded landings in 2001 (Fig. 4). The model generated for this forecast was:

$\mathrm{y}_{\mathrm{t}}=-0.007-0.058 \mathrm{y}_{\mathrm{t}-1}+\mathrm{a}_{\mathrm{t}}+0.950 \mathrm{a}_{\mathrm{t}-1}$

The model output indicated increased landings in $2002\left(1.71 .3 \mathrm{t} / \mathrm{km}^{2} /\right.$ year $)$ following the recorded catches in 2001 (1.3 t/ $/ \mathrm{km}^{2} /$ year $)$. Subsequent forecasts predicted a consistent decline in catches to the year 2011 with a shallow slope of $-0.01 \mathrm{t}$ / $\mathrm{km}^{2}$ (equation 2) (Fig. 4). The 95\% prediction limits indicated greater confidence in the forecasts during the next 4 years (2002-2005), with decreasing confidence (increasing confidence interval) in subsequent years.

\section{Exploitation and fishing mortality rates}

Analysis of length-frequency data (Fig. 5) for the three commercially important species yielded a higher asymptotic total length $\left(L_{\infty}\right)$ for the trumpet emperor (L. miniatus) $(46.2 \mathrm{~cm})$ than for the sky emperor (L. mahsena) $(37.8 \mathrm{~cm})$ and the whitespotted rabbitfish (S. sutor) $(39.9 \mathrm{~cm})$ (Table $3)$. Length-converted catch curves and Pauly's empirical formula yielded high total $(Z)$ and natural mortality $(M)$ rates for the sky emperor $(Z=3.84$, $M=1.36)$ and the whitespotted rabbitfish $(Z=2.59$, $M=1.15$ ) (Fig. 6). The trumpet emperor had the lowest mortality rates $(Z=1.83, M=0.90)$. Of the

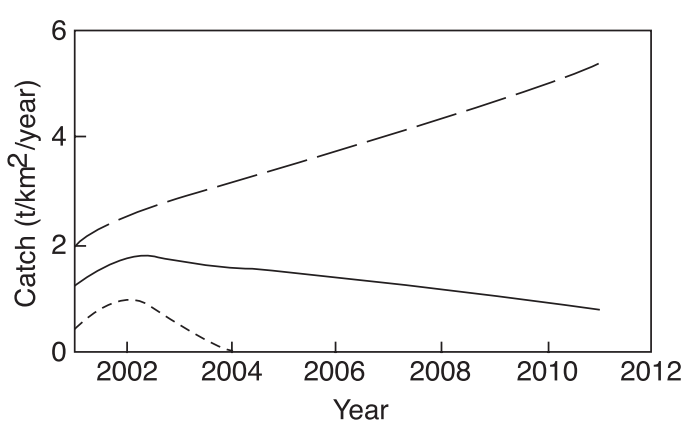

Fig. 4. Forecast landings of demersal coral reef fish in coastal Kenya for the next ten years (2002-2011). The middle line represents the mean forecast values while the upper and lower dashed lines are the corresponding $\mathbf{9 5 \%}$ confidence intervals.

three species, the sky emperor had the highest exploitation $(E=0.64)$ and fishing mortality $(F=2.59)$ rates. The trumpet emperor, L. miniatus, had lower rates $(\mathrm{E}=0.51, \mathrm{~F}=0.93)$, as did the whitespotted rabbitfish, $S$. sutor $(\mathrm{E}=0.56, \mathrm{~F}=1.44)$.

\section{DISCUSSION}

The data indicate that a rapid overall decline in landings occurred in coastal Kenya during the 1990s. The decline was most severe at Mombasa (78\%) which contributes $>40 \%$ of coastal landings and was less evident in some districts (e.g., Kwale). Environmental conditions could play a role in declining catches, but there is little evidence of large-scale change in climate along the East African coast in recent times. Annual human population growth rate in Kenya is estimated at $4.2 \%$ and the rate is thought to be higher in coastal towns (UNEP, 1998). Population-driven demand for food and

Table 3. Annual exploitation $(E)$ and mortality $(Z, M, F)$ rates and population growth parameters $\left(L_{\infty}, \mathrm{cm}\right.$, and $K / y e a r)$ of three commercially important coral reef fish species from coastal Kenya derived from length-frequency analysis of fisheries landing data from May 2000 to January 2002. Parameters are explained in the text

\begin{tabular}{lcccccccrr}
\hline & & & & & & & \multicolumn{2}{c}{ Published values } \\
\cline { 6 - 9 } Species & $\mathrm{L}_{\infty}$ & $\mathrm{K}$ & $\mathrm{Z}$ & $\mathrm{M}$ & $\mathrm{F}$ & $\mathrm{E}$ & $\mathrm{L}_{\infty}$ & $\mathrm{K}$ \\
\hline Siganus sutor & 39.90 & 0.52 & 2.59 & 1.15 & 1.44 & 0.56 & $25-52.1^{\mathrm{a}}$ & $0.5-1.5^{\mathrm{a}}$ \\
Lethrinus mahsena & 37.80 & 0.75 & 3.84 & 1.36 & 2.48 & 0.64 & $28.3-60^{\mathrm{b}}$ & $0.1-0.3^{\mathrm{b}}$ \\
Lethrinus miniatus & 46.20 & 0.43 & 1.83 & 0.90 & 0.93 & 0.51 & $90.0^{\mathrm{b}}$ & $0.06-0.17^{\mathrm{b}}$ \\
\hline
\end{tabular}

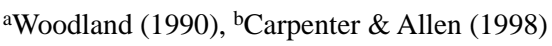



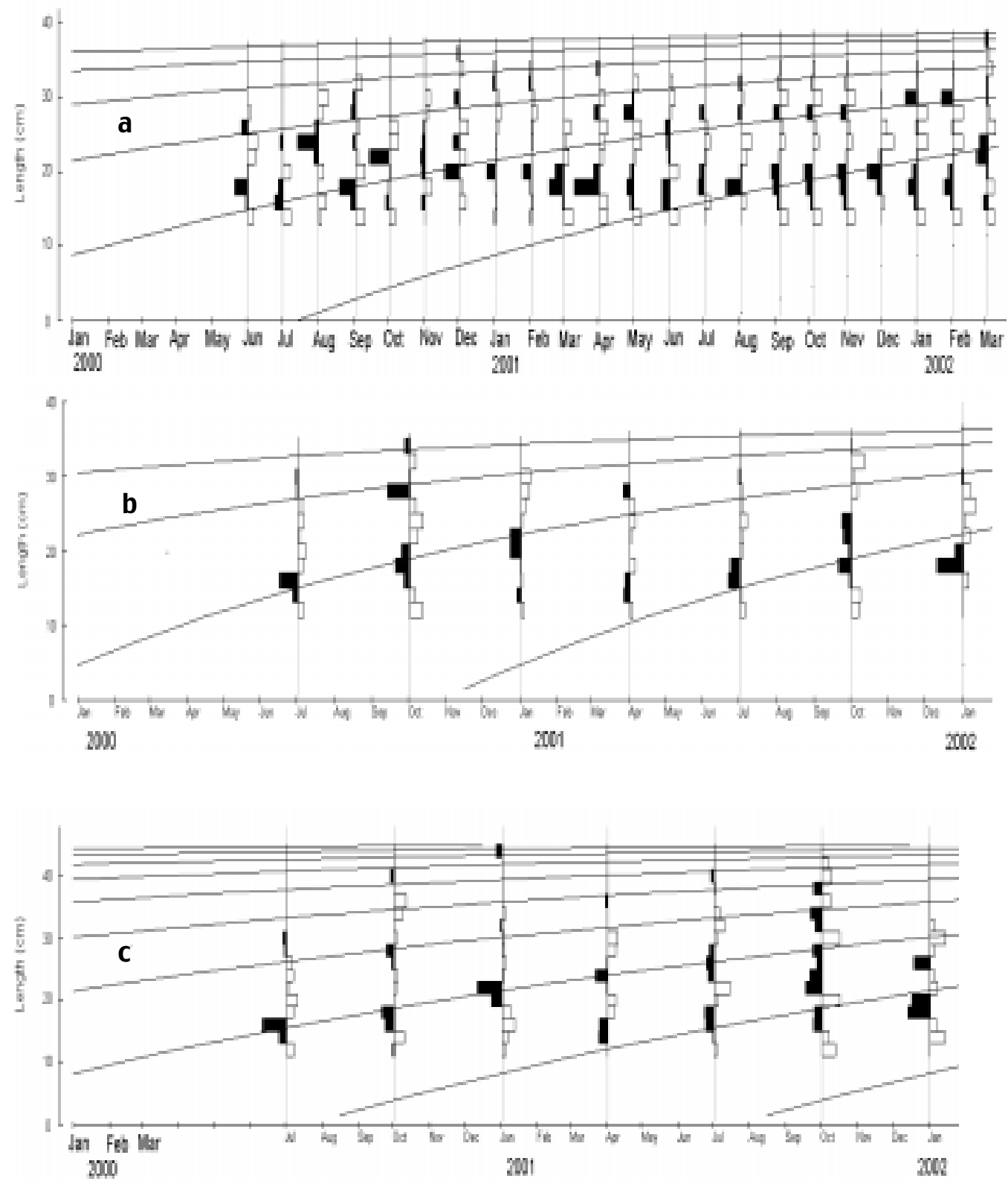

Fig. 5. The growth curves (continuous lines) of cohorts of (a) whitespotted rabbitfish, Siganus sutor (n=2253) (b) sky emperor, Lethrinus mahsena $(n=1232)$ and $(c)$ trumpet emperor, Lethrinus miniatus $(n=1035)$ from exploited reefs in coastal Kenya. Growth curves are superimposed over restructured length frequency data to generate peaks (black) as positive points and troughs (white), negative points. Generated growth parameters are shown in Table 3. 


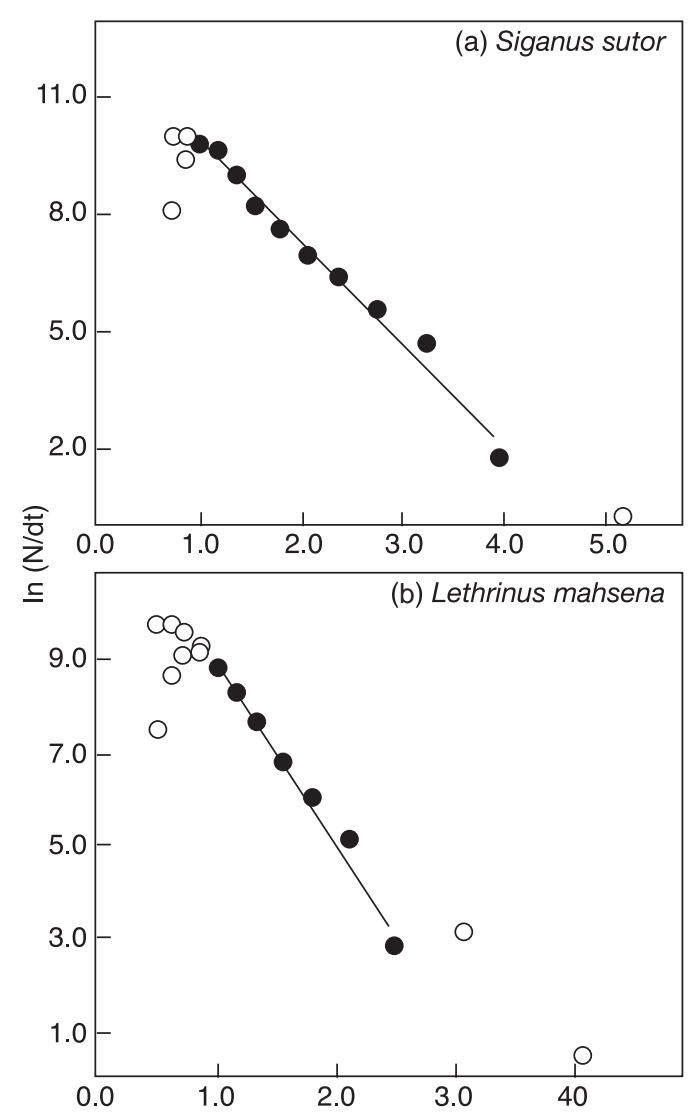

Fig. 6. Linearised length-converted catch curves for estimating annual instantaneous total $(Z)$ and natural mortality rates ( $M$ at $27^{\circ} \mathrm{C}$ ) for (a) Siganus sutor, (b) Lethrinus mahsena from exploited reefs in coastal Kenya. Data are fitted using ELEFAN II package in FiSAT. $N$ is number of fish in length class $i$ and $d t$ is time needed for fish to grow through the length class, sample sizes as in Fig. 5. Closed circles $(\bullet)$ used in the regression, open circles (o) not used.

employment, coupled with destructive fishing activities (McClanahan et al., 1997) has likely played a role in the recent decline in coastal landings.

The Siganidae and the Lethrinidae form the bulk $(\sim 40 \%)$ of the artisanal landings in coastal Kenya, and it is noteworthy that their landings declined by $40 \%$ during the 1990 s. The overall decline in landings is likely influenced greatly by the decline in the yield of the two groups. However, declines in all the major demersal fish families (e.g., Siganidae, Lethrinidae, Lutjanidae and Serranidae) have occurred over the last decade.
Fishing mortality and exploitation rates are above optimum levels for the commercially exploited species in these families. It is likely that sustainable yield levels have been exceeded. The lack of confidence limits of the FiSAT program parameter outputs (e.g. $K$ and $Z$ ) makes it difficult to assess the precision of the estimated mortality and exploitation rates and is a major drawback of the program (J.L. Munro, pers. comm.). However, precise estimation of sustainable yields is likely to be difficult due to the many landing sites, many gears and inappropriate records, a problem that is common for most tropical stocks (Russ, 1991).

It is noteworthy that the landings of the 'others' category is showing an increasing trend in recent years (Fig. 2h), and this has likely been caused by increased marketing of low trophic level species formerly considered less valuable. In coastal Kenya, the fisheries have shifted from hand-line capture for the large groupers to drive net, seine and gill net capture of low trophic level groups (e.g. Labridae and Acanthuridae). Similar results showing changes in reef fish community structure attributed to fishing have been reported for fished reefs in Jamaica (Koslow et al., 1988) and the Seychelles (Jennings \& Kaiser, 1998).

Amongst the families studied, the groupers (family Serranidae) showed an earlier and a steeper decline $(\sim 72 \%)$ in catches compared to the other groups. The groupers may have suffered high fishing mortality due to their sedentary life and the tendency to form spawning aggregations in some species (Thomson \& Munro, 1983), which makes them highly vulnerable to exploitation. It is likely that some serranids have suffered spawning collapse because of reduced population levels. Furthermore, fishing may skew sex ratios in protogynous (maturing as females) groups such as the Serranidae (Thomson \& Munro, 1983), thereby causing spawning failure. Elsewhere, the Nassau grouper, Epinephelus striatus, is commercially extinct in the Bermuda fishery (Luckhurst, 1996). The gonochoristic (separate sex) families (e.g., Lutjanidae, Lethrinidae, Siganidae) are likely to be more resilient under high fishing effort and the different reproductive ecology and behaviour may have allowed these groups to maintain stock levels without suffering dramatic declines as in the Serranidae. 
Earlier reviews of coral reef fish yields (Marshall, 1980) concluded that yields range from $0.8-5$ metric $\mathrm{t} / \mathrm{km}^{2} /$ year. However, studies of reeffish yields from American Samoa and the Philippines (Wass, 1982; Dalzel, 1996; Mapya et al., 2002) have documented yields in the range of $8-27 \mathrm{t} / \mathrm{km}^{2} /$ year. Our analysis of reef fish landings indicate that Kenyan reef-fish yields averaged 2.1 $\mathrm{t} / \mathrm{km}^{2} /$ year. However, this figure is likely conservative given that about $40 \%$ of the landings may not be reported (FAO, 1985). Therefore, potential yields may actually average $3-4 \mathrm{t} / \mathrm{km}^{2}$ / year. Yield estimates from different regions may not be strictly comparable because of the variations in reef area and type, depths, fishing intensity (Russ, 1991) and fish assemblages.

The continued decline in marine fisheries production may have been downplayed by the relatively small role of the marine fishery in national fisheries production; of Kenyan total annual fishery production, only $7.4 \%$ comes from marine waters (UNEP, 1998). There are a number of physical, climatic and economic factors that combine to constrain the marine fishery in Kenya. Firstly, the area of the continental shelf, to a depth of $200 \mathrm{~m}$, is only about $8500 \mathrm{~km}^{2}$, less than $10 \%$ of the fishable area of Lake Victoria (the largest freshwater lake in the country with landings $>100,000$ MT/year). Secondly, the South-East Monsoon which is prevalent from March to October is associated with very strong winds and rough currents. These conditions constrain the use of small dug-out canoes which are the main fishing craft. Thirdly, the East African coast does not have high productivity due to the oceanic origin of the coastal currents and lack of major upwelling areas (Hamilton \& Brakel, 1984). Despite these constraints and the low contribution to national production, marine fishery resources are locally important sources of livelihood and protein for coastal communities.

The conventional methods of regulating a fishery are often difficult to enforce in developing countries (McManus, 1997). Recent interest has focused on the use of marine reserves to complement traditional fisheries management methods. Marine reserves are straightforward and cost effective tools for managing overutilised resources in developing countries. Kenya has four national marine parks, and although these comprise less than $5 \%$ of the total reef area, they have been found to effectively conserve biodiversity and local fish biomass (McClanahan \& Kaunda-Arara, 1996). Reserves, appropriate traditional reef management methods (Johannes, 1978), improved fisheries data collection and effective gear regulation are complementary measures needed to manage overexploited stocks.

In conclusion, the trend analysis has shown that demersal coral-reef fish production has declined by over $50 \%$ for the total catches and $78 \%$ in the densely populated district (Mombasa) during the last decade. The principal commercial species are likely being exploited beyond optimal levels, and our forecast predicts a gradual decline in landings during the next decade. However, model forecasts are only instructive in terms of the direction of change while absolute forecast values are likely unreliable over a long-term (J. Wroblewski, pers. comm.). The causes of the declining trends cannot be determined from the present data, but human population driven increase in fishing effort as a result of increased demand for food may have played an important role. More detailed analysis will require improvement of the data collection system to include species records, catch per gear and the associated fishing effort.

Acknowledgements-We wish to thank the Director of Kenya Fisheries Department for permission to use the fish landing data. We thank C. Charo, J. Mumba and M. Ndegwa for recording research fish landing data. This work was completed with partial funding from the International Foundation for Science (IFS, Sweden).

\section{REFERENCES}

Box, G. E. P. \& Jenkins, G. M. (1976) Time series analysis. forecasting and control. Holden-Day, San Francisco.

Brochman, B. S. (1984) Fisheries development and economy. In: Iverson, S.A. \& Myklevoll, S. (eds). Proceedings of Norad-Kenya seminar to review the marine fish stocks and fisheries in eastern Africa. Bergen Institute of Marine Research. pp. 135-140.

Carpenter, K.E. \& Allen, G.R. (1998). FAO species catalogue. Vol. 9. Emperor fishes and large-eye 
breams of the world (family Lethrinidae). An annotated and illustrated catalogue of lethrinid species known to date. FAO species synop. No. 125 (9).

Cleveland, W. S. (1979) Robust locally weighted regression and smoothing scatterplots. J. Amer. Stat. Ass. 74: 829-836.

Dalzell, P. (1996) Catch rates, selectivity and yields of reef fishing. In: Polunin, N.V.C. \& Roberts, C.M. (eds), Reef fisheries. Chapman and Hall, London. pp. 161-192.

Drinkwater, K. F. \& Mountain, D. G. (2002) Climate and oceonography. In: Boreman, J., Nakashima, B.S., Wilson, J.A. \& Kendal, R.L. (eds) Northwest Atlantic groundfish: perspectives on a fishery collapse. Amer. Fish Soc. pp. 3-25.

Food and Agriculture Organization (1985) Results of the first year of implementation of the Kenyan catch assessment survey. FAO SWIOP / WP/18. FAO, Rome.

Food and Agriculture Organization (1995) The state of world fisheries and aquaculture. FAO, Rome. $125 \mathrm{pp}$.

Gayanilo Jr. F.C., Sparre, P. \& Pauly, D. (1995) The FAO-ICLARM stock assessment tools (FiSAT) user's guide. FAO computerized information series (Fisheries) No. 8. FAO, Rome. 124 pp.

Gulland, J. A. (1971) The fish resources of the ocean. Fishing News (Books), Ltd, for FAO, 255, Revised edition of FAO Fish. Tech. Pap. 97: 425 pp.

Hamilton, G. H. \& Brakel, W. H. (1984) Structure and coral fauna of East African reefs. Bull. Mar. Sci. 34: 248-266.

Hutchings, J. A. (2000) Collapse and recovery of marine fishes. Nature 406: 882-885.

Jennings, S. \& Kaiser, M. J. (1998) The effects of fishing on marine ecosystems. Adv. Mar. Biol. 34: 202-352.

Jennings, S. \& Lock, J. M. (1996) Population and ecosystem effects of fishing. In: Polunin, N.V.C. \& Roberts, C.M. (eds). Reef fisheries. Chapman and Hall, London. pp. 193-218.

Jennings, S. \& Polunin, N. V.C. (1996) Impacts of fishing on tropical reef ecosystems. Ambio 25: 44-49.

Jiddawi, N.S. \& Stanley, R.D. (Eds) (1999) Fisheries stock assessment in the traditional fishery sector: the information needs. Proceedings of the National Workshop on the Artisanal Fisheries Sector, Zanzibar, September 22-24, 1997 Zanzibar, Tanzania.

Johannes, R.E. (1978) Traditional marine conservation methods in Oceania and their demise. Ann. Rev. Ecol. Syst, 9, 349-364.

Koslow, J. A., Hanley, F. \& Wicklund, R. (1988) Effects of fishing on reef fish communities at Pedro Bank and Port Royal Cays, Jamaica. Mar.
Ecol. Prog. Ser. 43: 201-212.

Lauck, T., Clark, C. W., Mangel, M. \& Munro, G. R. (1998) Implementing the precautionary principle in fisheries management through marine reserves. Ecol. Appl. 8: 72-78.

Luckhurst, B. E. (1996) Trends in commercial fishery landings of groupers and snappers in Bermuda from 1975 to 1992 and associated fishery management issues. In: Arreguin-Sanchez, F., Munro, J.L., Balgos, M.C. \& Pauly, D. (eds). Biology, fisheries and culture of tropical groupers and snappers. ICLARM Conf. Proc. 48, 449 pp.

Mapya, A. P., Russ, G. R., Alcala, A.C. \& Calumpong, H. P. (2002) Long-term trends in yield and catch rates of the coral reef fishery at Apo Island, central Philippines. Mar. Freshw. Res. 53: 207-213.

Marshall, N. (1980) Fishery yields of coral reefs and adjacent shallow water environments. In: Saila, S.B. \& Roedel, P.M. (eds) Stock assessment of tropical small-scale fisheries. University of Rhode Island, Kingston. pp. 103-109.

McClanahan, T. R. (1995) Fish predators and scavengers of the sea urchin Echinometra mathaei in Kenyan coral-reef marine parks. Env. Biol. Fish. 43: $187-193$.

McClanahan, T. R. \& Kaunda-Arara, B. (1996) Fishery recovery in a coral-reef marine park and its effect on the adjacent fishery. Cons. Biol. 10: 1187-1199.

McClanahan, T. R. \& Obura, D. (1995) The status of Kenyan coral reefs. Coast Manage. 23: 57-76.

McClanahan, T. R., Glaesel, H., Rubens, J. \& Kiambo, R. (1997) The effects of traditional fisheries management on fisheries yields and the coral-reef ecosystems of southern Kenya. Env. Cons. 24: $105-120$.

McManus, J. W. (1997) Tropical marine fisheries and future of coral reefs. A brief review with emphasis on Southeast Asia. Coral Reefs 16: 121-127.

Munro, J. L. (1983) Caribbean coral reef fishery resources. ICLARM Studies and Reviews 7, Manila, Philippines.

Musick, J. A. (1999) Criteria to define extinction risk in marine fishes. Fisheries 24: 6-12.

O'Donovan, T. M. (1983) Short term forecasting: an introduction to the Box-Jenkins approach. John Wiley and Sons. N.Y.

Pauly, D. (1980) On the interrelationships between natural mortality, growth parameters, and mean environmental temperature in 175 fish stocks. Intern. J. Cons. Explor. Mer. 39: 175-192.

Pauly, D. (1984) Length-converted catch curves. A powerful tool for fisheries research in the tropics. Part II. ICLARM Fishbyte 1: 17-19.

Rose, G. A., deYoung, B., Kulka, D. W., Goddard, S. V. \& Fletcher, G. L. (2000) Distribution shifts and overfishing the northern cod (Gadus morhua): a 
view from the ocean. Can. J. Fish. Aquat. Sci. 57: 644-664.

Rothschild, B. J., Smith, S.G. \& Li, H. (1996) The application of time series analysis to fisheries population assessment and modeling. In: Gallucci, V.F., Saila, S.B., Gustafson, D.J. \& Rothschild, B.J. (eds). Stock assessment: quantitative methods and applications for small scale fisheries. CRC Lewis Publishers, Boca Raton, USA. pp. 354-402.

Russ, G. R. (1991) Coral reef fisheries. In: Sale, P.F. (ed.). The ecology of fishes on coral reefs. Academic Press, San Diego. pp. 601-635.

Sadovy, Y. (2001) The threat of fishing to highly fecund fishes. J. Fish Biol. 59: 90-108.

Thomson, R. \& Munro, J. L. (1983) The biology, ecology and bionomics of the hinds and groupers, Serranidae. In: Munro, J.L. (ed.). Carribean coral reef fishery resources (ICLARM Stud. Rev. 7), ICLARM, Manila, Philippines, pp. 94-109.

United Nations Environmental Programme (1998) Eastern Africa atlas of coastal resources, Kenya. UNEP, Kenya. 119 pp.

Wass, R. C. (1982) The shoreline fishery of American Samoa: past and present. In: Munro, J.L. (ed.). Marine and coastal processes in the Pacific: ecological aspects of coastal zone management. UNESCO-ROSTSEA, Jakarta. pp. 51-83.

Woodland, D.J. (1990). Revision of fish family Siganidae with description of two new species and comment on distribution and biology. Indo-Pacific Fish. 19: 136 pp.

Zar, J. (1975) Biostatistical analysis. Prentice Hall Inc. Eaglewood Cliffs, N.J. 